\title{
Kobiety Świadkowie Jehowy w nazistowskich obozach koncentracyjnych Przyczynek do charakterystyki społeczności kobiecych w lagrach
}

\author{
Jehovah's Witnesses Women in Nazi Concentration Camps \\ A Contribution to the Characteristics of Women's Communities in KZs
}

Aвstract: The article describes Jehovah's Witnesses women as one of less remembered groups among victims of the Nazi regime. What is pointed out, first of all, is the state of research on their history, especially pertaining to their camp experience, Western literature on the subject and a negligible number of Polish research works devoted to the topic in question, and also some methodological dilemmas related to researching it. The author presents the circumstances of German Jehovah's Witnesses after Hitler's seizure of power, their subsequent persecutions, and also - reconstructed on the basis of documents, witnesses reports, and the members of persecuted group themselves - the fate of female followers of this religion ("the purple triangles") in concentration camps. The author's main points of focus are, described by witnesses/beholders/ onlookers of the events, acts and attitudes of "the purple triangles" marked by strong spirituality, at the same time unbreakable/intransigent in their defiance of/against violence and the authorities' orders. (Everybody knew that Jehovah's Witnesses could have basically "sign off" from the camp by putting their signature at the bottom of a declaration that they would renounce their faith and cease to practise their religion.) Such a defiance may be better understood, the author claims, by interpreting it in the light of the anthropological concept of emotional communities.

KEY WORDS: Nazi persecution of Jehovah's Witnesses, German concentration camps, women Jehovah's Witnesses, literature of Jehovah's Witnesses, Jehovah's Witnesses in lager relations

„Nie jestem Świadkiem Jehowy. Nie miałem i nie mam wiele zrozumienia dla ich religii, jednakże niewzruszoność, z którą głoszą swoje poglądy, zrobiła 
silne wrażenie nie tylko na mnie"1 - tak były więzień polityczny Sachsenhausen wspominał współosadzonych wyznawców Jahwe. Jak wskazują inne relacje lagrowe, ta niewielka grupa kobiet i mężczyzn, którą oznaczono w obozach koncentracyjnych fioletowym trójkątem, oddziaływała na otoczenie w sposób zupełnie nieproporcjonalny do jej liczebności. Teresa Wontor-Cichy swoją niewielką monografię Więzieni za wiarę. Świadkowie Jehowy w KL Auschwitz opatrzyła mottem z wypowiedzi historyczki Christine King: „Im bardziej byli uciskani, tym mocniej zwierali szeregi, a ich opór nabierał twardości diamentu”2, a niemiecki badacz historii Hans Hesse zatytułował redagowane przez siebie dzieło zbiorowe traktujące o losie tej grupy pod hitlerowskim reżimem: Najodważniejsi byli zawsze Świadkowie Jehowy...

Lagrowa historia Świadków Jehowy, zrekonstruowana na podstawie dokumentów i relacji obserwatorów, nie tylko więc jawi się jako zajmująca, ale stanowi też przedmiot rzucający nowe światło na samych jego badaczy i deskryptorów. Nie uprzedzajmy jednak faktów...

1.

Rdzeń religii Badaczy Pisma Świętego (od 1931 roku Świadków Jehowy³) stanowi koncepcja eschatologiczna; w ich przekonaniu apokalipsa (Armagedon)

${ }^{1}$ Wypowiedź Fritza Bringmana w: Niezłomni w obliczu prześladowań. Świadkowie Jehowy a hitleryzm. Film o charakterze dokumentalnym. Dostępne w Internecie: https://www.youtube. com/watch? $v=n 5 V 2 T p C 8 Y k 0,0: 27: 46-0: 28: 04$ [data dostępu: 05.2019]. Zob. dyskusję o filmie: J. Wróbel: Dokumentacja wideo „Niezłomni w obliczu prześladowań” - propaganda czy dokument historii nowożytnej? W: Najodważniejsi byli zawsze Świadkowie Jehowy: prześladowania i sprzeciw Świadków Jehowy w okresie reżimu hitlerowskiego. Oprac. H. Hesse. Przeł. A. Boczek, J. Boczek. Wrocław 2006, s. 260-285; G. Yonan: Świadkowie Jehowy w Niemczech w przeszłości i obecnie. Religioznawcza analiza filmu dokumentalnego „Niezłomni w obliczu prześladowań”. W: Najodważniejsi byli zawsze..., s. 286-295; W. Slupina: „Niezłomni w obliczu prześladowañ” Świadkowie Jehowy a hitleryzm. Wystawy i prezentacje filmowe w Niemczech w latach 1996-2005. W: Najodważniejsi byli zawsze..., s. 296-309.

2 T. Wontor-Cichy: Więzieni za wiarę. Świadkowie Jehowy w KL Auschwitz. Oświęcim 2003, s. 2.

${ }^{3}$ W 1931 r. nazwa Świadkowie Jehowy zaczęła dotyczyć wyznawców i wyznawczyń Jehowy skupionych wokół Towarzystwa Strażnica. Jednak potocznie, a także w języku urzędowym Trzeciej Rzeszy Świadków Jehowy nadal określano jako Badaczy. Dlatego w archiwach obozowych natrafiamy na terminy Bibelforscher - „Badacz Pisma Świętego” / Bibelforscherka - „Badaczka Pisma Świętego”, albo skrót IBV, czyli Internationale Bibelforschervereinigung - Międzynarodowe Stowarzyszenie Badaczy Pisma Świętego (używano skrótów: BiFo, Bifo lub IBV). Zob. T. Wontor-Cichy: Wstęp. W: TAŻ: Więzieni za wiarę..., s. 7. Więźniami obozów byli Świadkowie Jehowy i Badacze Pisma Świętego, nie mamy jednak pewności, czy w relacjach współwięźniów 
urzeczywistni się w „czasach końca”, które przypadają na współczesność. To przeświadczenie kształtuje praktykę ich życia i, co nas tutaj szczególnie interesuje, determinowało ono postawę świadków wobec drugiej wojny światowej ${ }^{4}$. Wszystkie instytucje (poza własną organizacją), każdy rodzaj zwierzchności uznawali za szatański i przyjmowali wobec niego postawę neutralną. W przypadku polityki nazizmu oznaczało to brak zaangażowania $\mathrm{w}$ formy działania państwa i odmowę oddawania honorów władzy (uczestniczenia w wyborach, śpiewania hymnu, czczenia flagi, używania pozdrowienia hitlerowskiego, służby wojskowej i paramilitarnej, pracy na rzecz wojny). Wrzesień 1939 roku Świadkowie Jehowy zinterpretowali jako początek rozpadu dotychczasowego porządku i sygnał nadejścia Jezusa. Silna niezależność duchowa wyznawczyń i wyznawców Jehowy oraz ich odcięcie się od regulacji, które narzucała Trzecia Rzesza, sprawiły, że stali się oni przedmiotem hitlerowskich represji, ofiarami ataków bojówek, brutalnych rewizji, aresztowań. Tropiono wszelką religijną literaturę, a jej kolportaż i posiadanie stały się jednym $\mathrm{z}$ cięższych przestępstw. Nie tylko rekwirowano i niszczono osobiste księgozbiory, ale też zajmowano biura oraz redakcje. Organizację Świadków Jehowy rozwiązano na krótko po przejęciu władzy przez narodowych socjalistów, w kwietniu 1933 roku przejęto główną agencję prasową w Magdeburgu i zakazano wszelkich działań w ramach tej wspólnoty, a jej aktywność zakwalifikowano jako wrogą państwu.

Pierwsza więźniarka IBV została zatrzymana w Moringen (zakład penitencjarny dla kobiet poprzedzający KL Ravensbrück) w styczniu 1935 roku, mężczyźni Świadkowie Jehowy zaś trafili do Dachau w maju 1935 roku. Później kierowano ich również do Sachsenhausen, Buchenwaldu, Bergen-Belsen, Niederhagen-Wewelsburg, Dora-Mittelbau. Historycy szacują, że w obozach koncentracyjnych osadzonych zostało w sumie ponad 3000 kobiet i mężczyzn z kategorii „Świadkowie Jehowy” (ponad 2000 osób pochodziło z Niemiec, około 200-250 osób z Holandii, około 200 osób z Austrii i około 100 osób z Polski) ${ }^{5}$.

i współwięźniarek pojawiają się właściwe, czy jedynie obiegowe wskazania. We wspomnianej pracy Teresa Wontor-Cichy stosuje zasadę ogólnego określenia „IBV”, natomiast „Świadkowie Jehowy" w odniesieniu do konkretnych osób, ponieważ, jak podaje, na razie nie udało się dotrzeć do przekazów Badaczy Pisma Świętego. W niniejszym artykule również zastosuję to nazewnictwo, jednak w przypadku wspomnień współwięźniów i współwięźniarek będę respektować sugerowane przez nich terminy.

${ }^{4}$ „Podstawową koncepcją pozwalającą ustalić porządek wydarzeń czasów końca było uporządkowanie przez Ch.T. Russela periodyzacji dziejów zbawienia. Dokonał on, jak sam to określał, »odcyfrowania« Boskiego Planu Wieków, czyli przedstawienia sposobu, w jaki Bóg zamierzał zbawić ludzkość. [...] Russel podkreślał, że pewne proroctwa biblijne mogą być zrozumiane dopiero w czasie im właściwym, który właśnie teraz nadszedł" (W. WŁoch: Stosunek Świadków Jehowy do wojen pierwszej połowy XX wieku. Doktryna i praktyka. „Zeszyty Naukowe Uniwersytetu Jagiellońskiego. Studia Religiologica" 2003, Vol. 36: Religie a wojna i terroryzm, s. 133).

${ }^{5}$ Zob. D. Garbe: Zwischen Widerstand und Martyrium. Die Zeugen Jehovas im „Dritten Reich". München 1999 (wyd. I - 1993), s. 484. 
Przynajmniej do pierwszej połowy lat 90. Świadkowie Jehowy niknęli wśród wszystkich nazistowskich ofiar, a naukowa literatura przedmiotu nie uwzględniała ich jako osobnej grupy. Dzisiaj, kiedy w muzeach istniejących na terenie dawnych obozów koncentracyjnych upamiętniane są kolejne, pomijane dotąd społeczności więźniarskie (słabiej reprezentowane narodowości, mniejszości etniczne, seksualne i religijne), pojawiają się też symbole komemoracji Świadków Jehowy. W Ravensbrück tablicę im poświęconą odsłonięto w kwietniu 2012 roku (była to piąta taka tablica, wcześniej podobne inskrypcje pojawiły się w Neuengamme, Sachsenhausen, Dachau i Buchnewaldzie, w 2014 roku odsłonięto tablicę w Mauthausen-Gusen).

W polskich badaniach nad doświadczeniem obozów koncentracyjnych oraz jego zapisami literatura podmiotu i przedmiotu związana z "fioletowymi trójkątami” znajduje się na marginesie zainteresowania - obydwie istnieją, rzec można, incydentalnie i... chyba nieco kłopotliwie, w przestrzeni, powiedziałabym, konsternacji. Zajmijmy się najpierw literaturą przedmiotu.

Główne źródła wiedzy o losach Świadków Jehowy zostały opracowane przez badaczy niemieckich, co jest naturalne, ponieważ doświadczenie nazistowskich prześladowań dotknęło najpierw najszerzej wyznawców pochodzących z Trzeciej Rzeszy. Fundamentalnym historycznym studium pozostaje wydana w 1993 roku obszerna, ponad sześciusetstronicowa praca Detlefa Garbe Zwischen Widerstand und Martyrium. Die Zeugen Jehovas im „Dritten Reich” („Między ruchem oporu a męczeństwem. Świadkowie Jehowy w Trzeciej Rzeszy”), wznawiana i przełożona na język angielski, ale nietłumaczona na język polski. Ta, szeroko wykorzystywana przez historyków wojny, monografia jest w aspektach dotyczących Świadków Jehowy szczegółowa (włącza studium przypadku), a jednocześnie prezentuje ich doświadczenie na szerokim tle historycznym i ideologii nazizmu. Opiera się na zróżnicowanych źródłach: wcześniej nieuwzględnianych archiwaliach, krytycznych analizach literatury Świadków Jehowy, wywiadach z ocalałymi z obozów koncentracyjnych. Ich prześladowania pokazuje w kontekście innych represji, a tym samym $\mathrm{w}$ pewnym stopniu dekonstruuje historiografię Świadków Jehowy pisaną przez nich samych. Garbe przedstawia historię Międzynarodowego Stowarzyszenia Badaczy Pisma Świętego, założenie IBSA (rocznika Świadków Jehowy), rozwój stowarzyszenia w Republice Weimarskiej oraz Trzeciej Rzeszy, próby dostosowania się do polityki Hitlera, powstanie Towarzystwa Strażnica, opór i represje przed wojną i w jej trakcie, losy Świadków Jehowy osadzonych w obozach

${ }^{6}$ Por. tamże. „Według danych obozowego ruchu oporu 21 sierpnia 1944 roku więzionych było 100 kobiet i 22 mężczyzn oznaczonych kategorią IBV” (T. Wontor-CichY: Więzieni za wiarę..., s. 11).

7 D. Garbe: Between Resistance and Martyrdom: Jehovah's Witnesses in the Third Reich. Transl. D.G. Grimm. Madison, Wis. 1993. Amerykańskie wydanie jest obszerniejsze niż niemieckojęzyczny oryginał, zawiera bowiem materiał fotograficzny. 
koncentracyjnych ( $\mathrm{z}$ wyszczególnieniem Neuengamme) oraz ich sytuację po wojnie.

Dla humanisty zainteresowanego krytyczną analizą literatury pisanej przez Świadków Jehowy kluczową pracą musi być rozbudowana monografia Justyny Haas Erinnerungsliteratur von Jehovas Zeugen als NS-Opfern ${ }^{8}$ („Literatura pamięci Świadków Jehowy jako ofiar narodowego socjalizmu”). Dotychczas nie przetłumaczono jej na język polski, pomimo że uwzględnia się w niej sytuację polskich Świadków Jehowy pod okupacją hitlerowską oraz uniwersalne, kulturowe i literackie aspekty opisu obozowego doświadczenia i Holokaustu. Założeniem pracy jest rewaluacja tekstów pamięci Świadków Jehowy jako bagatelizowanej dotąd i nierozumianej grupy ofiar. Autorka bierze pod uwagę historię ich prześladowań w Niemczech, Austrii i Polsce, rozważa istotę konfliktu ich doktryny $\mathrm{z}$ tezami polityki nazizmu. Korzysta $\mathrm{z}$ często nieznanych i niedawno ujawnionych świadectw, stosuje nowoczesne antropologiczne i kulturowe modele lektury, zestawia materiał z przekazami innych ofiar (na przykład Żydów). Oprócz tego dokonuje swoistego résumé $\mathrm{w}$ dziedzinie studiów nad statusem świadka i świadectwami Holokaustu, analizuje problem biografii i autobiografii świadka, pamięci (również $\mathrm{w}$ aspekcie interdyscyplinarnym) oraz rozważa szczególną pozycję dokumentów powstałych w obozie i etapy tworzenia relacji (narracji) po prześladowaniach. Przedmiotem uwagi badaczki są także świadectwa mówione i nietekstualne ich elementy. Justyna Haas analizuje zarówno stricte literackie przekazy (utwory poetyckie), jak i egodokumenty: listy z okresu prześladowań, $\mathrm{z}$ więzienia, listy pożegnalne i pisane po wojnie. Materiał ten sytuuje $\mathrm{w}$ perspektywie problemów związanych $\mathrm{z}$ pamięcią osobistą i zbiorową oraz kulturowym deficytem pamięci niektórych grup prześladowanych.

Tym samym niemiecka autorka wprowadza świadectwa „fioletowych trójkątów" na poziom dyskursu o całości doświadczenia obozu i Holokaustu, mierzy się z dylematem, który, jak mi się wydaje, mógłby zainteresować reprezentantów rodzimej humanistyki. Mam tu na myśli szukanie dla relacji Świadków Jehowy specjalnego miejsca w porządku interpretacyjnym, ale i moralnym - bo właśnie taką sytuację może narzucać skrajnie nasycony religijnym mistycyzmem przedmiot badania. Chodzi tutaj o wypracowanie strategii analitycznego podejścia nie tylko do relacji samych Świadków Jehowy, ale też opracowań o charakterze naukowym, jednak napisanych także przez Świadków Jehowy, i niepozbawionych jakże czytelnego przesłania religijnego (więcej o tym piszę nieco dalej).

Justyna Haas wystąpiła też w roli tłumaczki na język niemiecki niedużej książki będącej pierwszą polską próbą historycznego ujęcia tematu więźniarek i więźniów Świadków Jehowy w KL Auschwitz - mowa o wymienianej już pracy badaczki Teresy Wontor-Cichy Więzieni za wiarę. Świadkowie Jehowy

\footnotetext{
${ }^{8}$ J. HAas: Erinnerungsliteratur von Jehovas Zeugen als NS-Opfern. Frankfurt am Main 2013.
} 
w KL Auschwitz (Oświęcim 2003) ${ }^{9}$. Chronologia faktów to jednak tutaj zaledwie ponad dwadzieścia stron opracowania, w tym opis sytuacji Świadków Jehowy w KL Auschwitz w uzasadnionym podziale na kobiety i mężczyzn; resztę stanowi materiał źródłowy w postaci imiennego wykazu więźniarek i więźniów. Ponadsześćdziesięciostronicowy aneks zawiera reprodukcje dokumentów, kilka relacji Świadków i bogaty materiał fotograficzny. (Teresa Wontor-Cichy jest również autorką ekspozycji muzealnej poświęconej temu samemu tematowi. Czasową wystawę „Więzieni za wiarę. Świadkowie Jehowy w KL Auschwitz” prezentowano najpierw (od września 2004 roku) w Państwowym Muzeum Auschwitz-Birkenau w Oświęcimiu, później w Muzeum Stutthof w Sztutowie, Muzeum Gross-Rosen w Rogoźnicy i w innych miejscach pamięci).

Rozproszone informacje na temat kobiet Świadków Jehowy i ich losów w KL Ravensbrück przynosi monograficzna książka Sarah Helm Kobiety $z$ Ravensbrück... ${ }^{10}$. Praca ta jest napisana $\mathrm{w}$ modnym teraz stylu dziennikarstwa historycznego i nie prezentuje co prawda uporządkowanych historii tej grupy w meklemburskim obozie, ale przedstawia - często za pośrednictwem współwięźniarskich relacji - sytuacje z udziałem wyznawczyń i ich osobiste przypadki. Jeśli chodzi o dane liczbowe dotyczące Świadków Jehowy w obozie, to Helm podaje je za monografią Bernharda Strebla KL Ravensbrück... ${ }^{11}$, ten zaś przytacza je (jak większość badaczy) z opracowania Detlefa Garbe.

Kontrowersyjną, choć ważną pozycję stanowi, przetłumaczona na język polski, praca zbiorowa pod redakcją niemieckiego historyka Hansa Hessego Najodważniejsi byli zawsze Świadkowie Jehowy: prześladowania i sprzeciw Świadków Jehowy w okresie reżimu hitlerowskiego ${ }^{12}$. W Polsce książkę sygnuje popularnonaukowe wydawnictwo „A Propos”, które opublikowało kilka innych tytułów związanych z historią Świadków Jehowy ${ }^{13}$. Tom otwiera (po Przedmowie) krótki artykuł Henry’ego Friedlandera prezentujący różne kategorie więźniów w obozach koncentracyjnych i - fakt ten wart jest uwagi - nie pozostaje ów rozdział ściśle powiązany z głównym tematem książki. Friedlander, były więzień KL Auschwitz, mówi o Świadkach Jehowy i ich pozycji wynikającej z prześladowań za

9 T. Wontor-Cichy: Für den Glauben in Haft: Zeugen Jehovas im KL Auschwitz. Aus dem poln. Übers. A. BoczeK, J. HaAs. Oświęcim 2006.

${ }^{10}$ S. HeLm: Kobiety z Ravensbrück. Życie i śmierć w hitlerowskim obozie koncentracyjnym dla kobiet. Przeł. K. Bażyńska-СhојNacka, P. Снојnacki. Warszawa 2017.

${ }^{11}$ B. Strebel: KL Ravensbrück. Historia kompleksu obozów. Przeł. A. Milewska, M. Kurkowska. Słowo wstępne do wyd. pol. A. Gawlikowska-Świerczyńska, J. Muszkowska-Penson. Słowo wstępne G. Tillion. Gdańsk 2018.

${ }^{12}$ Najodważniejsi byli zawsze...

${ }^{13}$ M.in. historyczną niemiecką pozycję z 1938 r. - Franza Zürchera Krucjatę przeciwko chrześcijaństwu. Prezentowała ona prześladowania i los Świadków Jehowy w obozach koncentracyjnych. Dane i dokumenty potrzebne do jej powstania przemycano z niemieckich lagrów. Inne książki prezentujące wojenne losy Świadków Jehowy to: Hermine Schmidt Ocalona radość, Krzysztofa Bilińskiego Hiobowie XX wieku, Thanassisa Reppasa Nigdy więcej wojny. 
przekonania religijne, a potwierdzonej oznaczeniem fioletowym trójkątem, jako szczególnej. Dodatkowo supozycja historyka odnosi się do całego uniwersum $\mathrm{KL}$, a nie konkretnego obozu i jak się wydaje, stanowi tezę przesądzającą o obecności szkicu w tej pracy zbiorowej. Już tutaj chcę zwrócić uwagę na umieszczenie akcentu - wyjątkowość, precedensowość doświadczenia Świadków Jehowy powraca w książce jako leitmotiv znany z dyskusji dotyczącej Holokaustu. Warto wspomnieć, że monografista KL Ravensbrück Bernhard Strebel, odwołując się do ustaleń historyków: Garbego, Hessego i Hardera, podaje, że „Pojedyncze adnotacje "Nowe Salem" lub "adwentystka" pozwalają wysnuć wniosek, że fioletowym trójkątem oznaczano także członkinie mniejszych grup wyznaniowych i sekt"14. Kolejne artykuły (na przykład Christopha Daxelmüllera, Jürgena Hardera, Hansa Hessego, Sybil Milton, Kirsten John-Stucke i innych) pokazują sytuację Świadków Jehowy pod władzą nazizmu oraz w poszczególnych obozach koncentracyjnych, omawiają postawy i normy religijne wyznawców. Szczególnie ważny jest tutaj tekst Jürgena Hardera i Hansa Hessego Świadkowie Jehowy w kobiecym obozie koncentracyjnym Moringen. Sprzeciw kobiet wobec nazizmu. Autorzy charakteryzują grupę więźniarek Świadków Jehowy, uwzględniając liczebność, wiek, status społeczny, opisują najczęstsze powody osadzenia oraz heroiczne mikrohistorie kobiet ${ }^{15}$. Polskich czytelników może też zainteresować rozdział pióra Wolframa Slupiny Prześladowania i represje Świadków Jehowy w Polsce w latach 1939-1945 oraz 1950-1989.

Nota autorska Najodważniejsi byli zawsze Świadkowie Jehowy... nie pozostawia wątpliwości, że co najmniej sześciu $\mathrm{z}$ dwudziestu wspołautorów tej pracy naukowej pozostaje zawodowo związanych z instytucjami Świadków Jehowy lub ich czasopismami religijnymi, a bardzo wiele materiałów źródłowych znajduje się w naczelnym piśmie „Strażnica”. Przytoczmy fragment wstępu przeznaczonego dla polskich czytelników:

Nie tylko byli więźniowie obozów koncentracyjnych, ale również kręgi naukowe w szczególny sposób wyróżniają postawę Świadków Jehowy. Trafnie sformułował to Friedrich Zipfel, stwierdzając, że prześladowania Świadków Jehowy miały „całkiem niezwykły przebieg”. Także Detlef Garbe, historyk i dyrektor Muzeum Obozu Koncentracyjnego Neuengamme w pobliżu Hamburga wskazuje na "godną uwagi specyfikę" prześladowań Świadków Jehowy. Składają się na nią przede wszystkim następujące czynniki: - Świadkowie Jehowy byli jedną

${ }_{14}$ B. Strebel: KL Ravensbrück..., s. 160.

15 „Procentowy udział kobiet będących Świadkami Jehowy wynosił w czerwcu 1937 roku $17 \%$, w lipcu $28 \%$, w sierpniu $38 \%$, we wrześniu $46 \%$, w październiku $80 \%$, w listopadzie $51 \%$ i w grudniu 89\%" (J. HARDER, H. Hesse: Świadkowie Jehowy w kobiecym obozie koncentracyjnym Moringen. Sprzeciw kobiet wobec nazizmu. W: Najodważniejsi byli zawsze..., s. 42). Badacze interpretują te dane jako odpowiadające trzem falom aresztowań Świadków Jehowy. Po drugiej fali w 1936 r. więcej kobiet miałoby zająć kierownicze stanowiska w organizacji, a gwałtowny wzrost ich uwięzień w Moringen jesienią 1937 r. byłby następstwem tej sytuacji. 
z pierwszych prześladowanych grup; - stawiali zwarty i nieugięty opór wobec narodowego socjalizmu; - fioletowy trójkąt, którym oznaczano Świadków Jehowy wskazywał na szczególną pozycję tej grupy w obozach koncentracyjnych; - tworzyli najliczniejszą grupę w szeregach osób odmawiających służby wojskowej, skazanych przez sądy wojskowe na śmierć; - ze wszystkich religijno-światopoglądowych ugrupowań spotkały ich najdotkliwsze prześladowania. Godna uwagi jest jeszcze jedna osobliwość, w kobiecych obozach koncentracyjnych w Moringen, Lichtenburg i Ravensbrück kobiety będące Świadkami Jehowy stanowiły największą grupę więźniarek (w przypadku kobiecego obozu koncentracyjnego Ravensbrück powyższy fakt odnosi się do okresu do 1939 roku $)^{16}$.

Nie potrzeba wielkiej wnikliwości krytycznej, aby odsłoniła się stronniczość cytowanego przekazu", który „zasadniczo” nie mija się z prawdą, niemniej jednak... I tutaj zbliżam się do - delikatnej w tym wypadku - sfery metodologicznego problemu.

Jak w Latourowskiej sieci wszyscy aktorzy i okoliczności mają tutaj znaczenie: fakt, iż chodzi o wyznawców Jehowy właśnie; że przedmiotem uwagi są silnie zmistycyzowane świadectwa; że sami badacze są Świadkami Jehowy; że wydawnictwo sygnujące tę naukową w końcu pracę opublikowało też inne książki o takim religijnym charakterze. Również fakt, że my (czytelnicy, badacze) znajdujemy się najczęściej (statystycznie rzecz biorąc) po drugiej stronie zdualizowanego napięcia (religijnego), a przecież wiemy, że bycie po jednej ze stron może udaremnić przyswojenie jakiejś wiedzy, jakieś zrozumienie. Stąd między innymi wynika istotność wymienionej pracy Justyny Haas umieszczającej (niebezkrytycznie) relacje Świadków Jehowy na poziomie innych świadectw Holokaustu. Tym bardziej że (bywa) historycy niczego nie ułatwiają wszak już sam tytuł książki: Najodważniejsi byli zawsze Świadkowie Jehowy..., zawiera supozycję wartościującą, a Wstęp pióra Michaela Berenbauma wskazuje wprost na naczelną pozycję ich cierpienia („[...] w niniejszej przedmowie chciałbym umiejscowić Świadków Jehowy w szeregu ofiar nazizmu, a przede wszystkim wyjaśnić, co wyróżnia ich wyjątkowe przeżycia”) ${ }^{18}$. Materiał do dyskusji mógłby stanowić fakt, że w przypadku osadzenia w obozie osób Żydów-Świadków Jehowy (zarazem) powody uwięzienia określano jako rasowe, nie zaś religijne ${ }^{19}$.

${ }^{16}$ H. Hesse: Przedmowa do polskiego wydania. W: Najodważniejsi byli zawsze..., s. 9.

${ }_{17}$ Por. np. „W pierwszej kolejności ostrze terroru skierowano na przeciwników politycznych, w szczególności na zorganizowany ruch robotniczy. Wraz ze stopniowym kształtowaniem się reżimu narodowosocjalistycznego prześladowania dotykały kolejne grupy społeczne. W latach poprzedzających wojnę można wyróżnić sześć fal radykalizacji prześladowań, wymierzonych w następujące grupy: w przeciwników politycznych (od 1933 r.), świadków Jehowy (od 1935 r.), homoseksualistów (od 1935 r.), osoby uprzednio karane (tzw. kryminalnych, od 1937 r.), »aspołecznych" (od 1938 r.) i w Żydów (od 1938 r.)” (B. StrebeL: KL Ravensbrück..., s. 45).

${ }_{18}$ Najodważniejsi byli zawsze..., s. 14.

${ }_{19}$ Por. T. Wontor-Cichy: Więzieni za wiarę..., s. 11. 
Powiedzieć też trzeba, że praca Najodważniejsi byli zawsze Świadkowie Jehowy... ma niewielki potencjał autokrytyczny - zawiera na przykład dyskusję o dosyć znanym, szeroko rozpowszechnianym dokumencie wizualnym Niezłomni w obliczu prześladowań... ${ }^{20}$.

Herman Hesse występuje także w roli badacza rekomendującego popularne wydawnictwa poświęcone Świadkom Jehowy, jest między innymi autorem Przedmowy do obszernych, przetłumaczonych na język polski wspomnień Simone A. Liebster $W$ paszczy lwa. Mała dziewczynka stawia czoło reżimowi hitlerowskiemu ${ }^{21}$. Wspominam o tej akurat książce, ponieważ z perspektywy dziecięcej oraz kobiecej obszernie i drobiazgowo prezentuje ona przebieg prześladowań Świadków Jehowy w Niemczech (wraz z historią uwięzienia i osadzenia w obozie rodziny autorki). Infantylizm przynależny tej relacji (nieobcy niestety i innym jej pokrewnym) czytelnik może potraktować bardziej ulgowo z uwagi na wiek narratorki. (Ale nie dajmy się zwieść naiwności jako figurze uprawdopodobnienia, nie jest ona bezinteresowna i mimowolna, publikacje takie jak $W$ paszczy lwa... zostają bowiem przygotowane po to, aby aspirowały do rangi poważnego dokumentu historycznego; służą temu na przykład rozdziały wprowadzające w tym wypadku oprócz Przedmowy Hessego mamy Komentarz historyczny pióra Abrahama J. Pecka oraz Wstęp Sybil Milton).

Ponieważ obozowy los kobiet Świadków Jehowy jest znany jedynie z ich rozproszonych relacji zawartych $\mathrm{w}$ wymienionych opracowaniach i materiałach, tym bardziej warto zwrócić uwagę na obecne w języku polskim (dzięki przekładom) świadectwa innych więźniarek. Pozwalają one uchwycić interakcje i zbudować perspektywę „nie od religijnego środka”, jakkolwiek i ona nasycona jest swoistymi supozycjami. I tak dla obozowej, w tym aspekcie, historiografii oraz studiów nad zapisem doświadczenia lagrowego ważne są głosy wychwytujące odmienność w zachowaniach kobiet Świadków Jehowy i ją komentujące. Styk religii wewnątrzobozowej populacji tworzy w tym wypadku szczególną płaszczyznę wzajemnych relacji odbitych w tekstach, dodajmy raz jeszcze, niełatwych do zobiektywizowanej interpretacji i wykraczających poza, bardziej już uschematyzowane w społecznym odbiorze, implikacje współobecności katolików i Żydów.

${ }^{20}$ Zob. przyp. 1.

${ }^{21}$ S.A. Liebster: W paszczy lwa. Mała dziewczynka stawia czoło reżimowi hitlerowskiemu. Przeł. A. BoczeK. Wrocław 2007. 
Niniejszy artykuł mógłby właściwie nosić tytuł: „Świadkinie świadkiń”, nieco przekonceptualizowany - przyznaję - niemniej wprost wskazujący na istotność kobiecego aspektu doświadczenia Świadków Jehowy i rolę jego obserwatorek. Ponieważ to właśnie więźniarki (a nie więźniowie) Świadkowie Jehowy wyraźniej zapisały się w obozowej historiografii ${ }^{22}$.

Do wybuchu drugiej wojny światowej prześladowania obejmujące różne grupy społeczne i oporu dotykały kobiety w stopniu dużo mniejszym niż mężczyzn ${ }^{23}$. Wyjątek stanowiły właśnie kobiety Świadkowie Jehowy, które w stosunku do pozostałych najwcześniej i najliczniej trafiły do obozów koncentracyjnych. Od 1937 do 1939 roku były one największą społecznością więźniarek (po wrześniu 1939 roku rozpoczął się napływ do więzień i lagrów kobiet z krajów okupowanych). Wynikało to $\mathrm{z}$ faktu, że we wspólnocie Świadków Jehowy udział kobiet aktywnie uczestniczących w oporze był wyższy niż w innych protestujących grupach ${ }^{24}$. Jeszcze przed wojną potrafily one zbiorowo i manifestacyjnie występować przeciwko reżimowi Hitlera.

W 1936 roku pięćset niemieckich gospodyń domowych wzięło Biblie, założyło na głowy schludne białe chustki i przyjechało do Moringen. Kobiety, Badaczki Pisma Świętego, protestowały, kiedy ich mężowie dostali powołanie do wojska. Hitler to antychryst, mówiły; Bóg rządzi ziemią, nie Führer. Ich mężowie i inni badacze Pisma Świętego zostali wywiezieni do najnowszego obozu Hitlera, Buchenwaldu, gdzie dostali po dwadzieścia pięć batów skórzanym pejczem. Jednak Himmler wiedział, że jego esesmani nie są dość twardzi, żeby poturbować niemieckie gospodynie, więc w Moringen badaczkom Pisma Świętego biblie odebrał naczelnik więzienia - miły emerytowany żołnierz utykający na jedną nogę 25 .

Helm podaje również: „W dużym stopniu z powodu ich buntu w Lichtenburgu Koegel [komendant obozu Ravensbrück - B.C.] zażądał stworzenia bloku karnego w Ravensbrück. Kilka tygodni przed otwarciem obozu powiedział swojemu przełożonemu z SS Theodorowi Eickemu: "Nie uda się utrzymać porządku, dopóki te rozhisteryzowane wiedźmy nie zostaną spacyfikowane. Zwy-

${ }^{22}$ Np. Hermann Langbein, były więzień Auschwitz, dosyć analitycznie przedstawiający obozowe społeczeństwo w swej monografii i, siłą rzeczy, bardziej skupiony na jego męskiej części, o „męskich” fioletowych trójkątach wzmiankuje jedynie przy okazji komentarza dotyczącego oznaczeń więźniarskich: „Inne kolory tych trójkątów, którymi oznaczani byli więźniowie asocjalni (czarny winkiel), świadkowie Jehowy czy homoseksualiści, nie odgrywały większej roli w hierarchii więźniarskiej w Auschwitz" (H. Langbein: Ludzie w Auschwitz. Przeł. V. GrotoWICZ. Oświęcim 2017, s. 27).

${ }^{23}$ Zob. N. Wachsmann: Historia nazistowskich obozów koncentracyjnych. Przeł. M. Antosiewicz. Warszawa 2016, s. 155.

${ }^{24}$ Por. B. Strebel: KL Ravensbrück..., s. 46.

${ }^{25}$ S. Helm: Kobiety $z$ Ravensbrück..., s. 40. 
kłe pozbawienie jedzenia nie złamie ich bez dodatkowej formy rygorystycznego uwięzienia «" ${ }^{26}$. Autorka monografii o Ravensbrück ma tu na myśli zbiorowy bunt kobiet Świadków Jehowy, które w październiku 1938 roku odmówiły wysłuchania zwycięskiej mowy Hitlera po zajęciu przez niego Kraju Sudeckiego. Zostały wówczas zmasakrowane wodą puszczaną pod dużym ciśnieniem z węży przeciwpożarowych oraz pogryzione przez psy. Niektóre, przewracane i szarpane przez zwierzęta, głośno się modliły ${ }^{27}$. W Ravensbrück także masowo występowały przeciwko nakazowi prac na rzecz wojska - Helm nazywa je „pierwszymi wewnętrznymi wrogami obozu"28.

Obserwatorki i obserwatorzy obozowych zachowań Świadków Jehowy najczęściej porażeni byli ich aprobatą własnego cierpienia i poczuciem jego wyjątkowości. Nie tylko współwięźniowie oraz współwięźniarki, ale i lagrowe władze pozostawały pod wrażeniem uduchowionych, nieugiętych postaw. W znanej autobiograficznej relacji komendanta Auschwitz można wyśledzić wręcz fascynację ekstatycznością, z jaką Świadkowie Jehowy poddawali się karom, łącznie $\mathrm{z}$ najwyższą - karą śmierci' ${ }^{29}$.

Związek takich zachowań z doktryną Świadków Jehowy był bezpośredni doznawane represje oraz wynikające $z$ nich cierpienia były wolą Boga i miały stanowić dowód jej prawdziwości. Taką autoafirmację własnych prześladowań, jak podaje religioznawca, całkiem pragmatycznie wyzyskiwano przed wojną: „Towarzystwo nagłaśniało przypadki ataków na głosicieli, a czasami wprost zachęcało do prowokowania takich wypadków. Tak więc to oczekiwanie na ciągłe pogarszanie się sytuacji oraz na nieuchronne cierpienie wynikające $\mathrm{z}$ prześladowań przygotowywało postawę nieugiętego trwania $\mathrm{w}$ przeciwnoś-

\footnotetext{
26 Tamże, s. 58.

27 Por. tamże, s. 46.

28 Tamże, s. 85.
}

29 „Eicke wielokrotnie skazywał ich na karę chłosty za ich niezdyscyplinowanie. Karę tę przyjmowali z takim entuzjazmem, że można było ich posądzać niemal o perwersyjne skłonności. Prosili oni komendanta o dalsze kary, aby tym lepiej służyć swojej idei i Jehowie. Po przejściu przez komisję poborową, którą - jak można było przypuszczać - całkowicie zbojkotowali, odmówili nawet podpisania wojskowych dokumentów, zostali przez Reichsführera SS również skazani na śmierć. Kiedy ich o tym w areszcie zawiadomiono, ogarnęła ich nieopisana radość i zachwyt. Nie mogli się doczekać egzekucji. Wciąż składali ręce, patrzyli z zachwytem w górę i wołali bez przerwy: »Wkrótce będziemy u Jehowy, jakie to szczęście, że zostaliśmy do tego wybrani«. Parę dni przedtem byli obecni przy egzekucji swoich współwyznawców i nie można ich było wtedy utrzymać. Chcieli, aby ich również rozstrzelano. Nie można było patrzeć na to opętanie. Przemocą musiano ich zaprowadzić do aresztu. Na swoją egzekucję biegli niemal kłusem. Nie chcieli w żaden sposób dać się wiązać, aby móc podnieść ręce do Jehowy. W olśnieniu i zachwycie, które nie miały w sobie nic ludzkiego, stali przed drewnianą ścianą. Tak wyobrażałem sobie pierwszych chrześcijańskich męczenników oczekujących na arenie na rozszarpanie ich przez dzikie zwierzęta. Szli oni na śmierć z jasnym obliczem, skierowanymi ku górze oczyma, złożonymi do modlitwy i podniesionymi rękoma” (Autobiografia Rudolfa Hössa komendanta obozu oświęcimskiego. Przeł. W. Grzymski. Warszawa 1989, s. 86). 
ciach traktowanych jako próba"30. Ale badacz podaje też przykład więźnia obozu Stutthof, który rozważał powód, „dla którego jego »Bóg przysłał go do tego piekła«. Odpowiedział na to, iż »dzięki temu ma okazję głosić innym, a jego wiara może zostać wypróbowana " "31. Sara Helm przywołuje podobną postawę więźniarki Ravensbrück: „Był jeden ogromny walec i jeden mały. Do uchwytów walca przymocowano liny, kobiety chwytały za nie i ciągnęły. Przynajmniej to ubijanie drogi miało sens. Przewalanie piasku z górki na górkę - nie $e^{32}$. Wkrótce więźniarki znienawidziły piasek. Badaczki Pisma Świętego uważały, że praca została zaplanowana szczególnie dla nich, "aby zmusić je do porzucenia ich Boga", ale pozostałe wiedziały, że to Żydówki cierpią najbardziej: były słabsze i mniej nawykłe do ciężkiej pracy, twierdziły"33.

Niezależność duchowa od nazizmu, przyjęcie religijnego aspektu cierpienia i wzajemne skuteczne pobudzanie się Świadków Jehowy do zachowania normy etycznej musiało oddziaływać na obserwatorów. Anna Pawełczyńska ich konsekwentny opór określiła jako „zwartą siłę ideologiczną, która wygrała swą walkę z hitleryzmem" ${ }^{34}$. Niemniej odbiór takich postaw nie był jednolity. Literacki dokument Anji Lundholm Wrota piekieł. Ravensbrück prezentuje inne współwięźniarskie nastawienie:

Nachmann, nasza blokowa, z narastającym podenerwowaniem krąży wokół nas jak czujny pies pasterski; wpycha do szeregu stojące nieco z boku, złości się na brak dyscypliny wśród podległych jej więźniarek. Liliowy trójkąt na rękawie identyfikuje ją jako „badaczkę Biblii”. Dosłowna interpretacja Pisma Świętego oraz nakaz służenia i bezwzględnego posłuszeństwa władzy zwierzchniej ściąga na nią pogardę niejednej działaczki ruchu oporu. - Precz z łapami - mówi Petzold, tramwajarka, aresztowana za przyjazne uczucia wobec poszukiwanego komunisty - albo zaraz oberwiesz kanalio ${ }^{35}$.

Oprócz rzeczy oczywistych ten cytat uświadamia coś jeszcze, mianowicie trudność lekturowej interpretacji - nie wszystko jest łatwe do zrozumienia po drugiej stronie religijnego napięcia.

Dla ludzi, dla których jedyną instancją był Jehowa, a absolutne posłuszeństwo jego woli wyznaczało normy postępowania, jednocześnie kwestią wyboru

${ }^{30}$ W. WŁoch: Stosunek Świadków..., s. 136.

31 Tamże.

${ }^{32}$ Jako specjalną formę udręczenia Niemcy często stosowali w obozach absurdalne prace, $\mathrm{np}$. przesypywanie piasku z górki na górkę, przenoszenie wykopanej ziemi z miejsca na miejsce i z powrotem itp.

${ }_{33}$ S. Helm: Kobiety $z$ Ravensbrück..., s. 63.

34 A. PaweŁczyńska: Wartości a przemoc. Zarys socjologicznej problematyki Oświęcimia. Warszawa 1995, s. 108-109.

35 A. Lundholm: Wrota piekiet. Ravensbrück. Przeł. E. Czerwiakowska. Warszawa 2013, s. 10. 
pozostawało, jaka rzecz w tej dążności się mieści. Granica sprzeciwu i uznanie, co jeszcze nie, a co już kwalifikuje się jako sprzeczne z zamierzeniem Bożym, były $\mathrm{w}$ praktyce indywidualne i elastyczne, konsekwencje jej przebiegu zaś zwykle dojmujące, czasem ostateczne. (Na przykład jesienią 1942 roku grupę kobiet Świadków Jehowy o poglądach zdecydowanie przeciwnych polityce Hitlera wysłano z meklemburskiego lagru do Auschwitz i ostatecznie, po ponownym przywiezieniu do Ravensbrück, je stracono ${ }^{36}$ ).

To z kolei, co znalazło się poza cezurą odmowy, wykonywane było bardzo solidnie - stąd bierze się zdyscyplinowana postawa funkcyjnej „Bibelki” z przywołanego cytatu, rozumiana przez polityczne współwięźniarki dosłownie, jako prosta spolegliwość wobec obozowej władzy. Prace oprotestowane przez niektóre więźniarki przez inne były wykonywane z oddaniem. Stąd musimy zrozumieć, że część kobiet Świadków Jehowy bez sprzeciwu obsługiwała bunkier, w którym osadzano przede wszystkim więźniarki polityczne ${ }^{37}$, i należycie sprawowała obowiązki funkcyjnych, część zaś nie godziła się na to jako sprzeczne z wolą Jahwe. Historyczne przykłady mogą cokolwiek powiedzieć o praktyce takiego podejścia. Wanda Kiedrzyńska, była więźniarka Ravensbrück i monografistka tego obozu, pisze:

Bardzo surowo rozprawiano się z badaczkami Pisma świętego, gdy w grudniu 1939 roku odmówiły robienia paczek świątecznych dla żołnierzy. W ogóle nie chciały one bezpośrednio pracować dla wojska. 19 grudnia zabrano je do bunkra na 4 tygodnie. Zdjęto im jaki i chustki i kazano stać w samych sukniach na podwórku więziennym od 3 do 5 godzin. A mrozy dochodziły wówczas do 40 stopni! Co czwarty dzień dostawały po $1 / 2$ porcji kawy rano i wieczorem, co ósmy dzień $1 / 4$ porcji obiadu ${ }^{38}$.

A oto fragment relacji Elżbiety Abt, więzionej „za Jehowę” w KL Auschwitz:

Nadszedł czas przydzielania nam pracy. Zapytano nas: „Gdzie która chce pracować?” nie odpowiedziałyśmy ani słowa. „No co, takie jesteście dumne?” zareagowała na to strażniczka. „Nie jesteśmy dumne” - odpowiedziała moja przyjaciółka - „ale gdziekolwiek nas dacie, tam będziemy pracowały”. I tej zasady trzymałyśmy się zawsze. Nie chciałyśmy wybierać sobie miejsca pracy, skoro prosiłyśmy Jehowę o kierownictwo. Gdyby warunki okazały się zbyt ciężkie, wówczas mogłyśmy spokojnie zwrócić się do Niego i prosić: „Jehowo, teraz racz nam pomóc"39.

${ }^{36}$ Zob. S. Helm: Kobiety z Ravensbrück..., s. 323.

${ }^{37}$ Por. W. KiedrzyŃsKa: Ravensbrück. Kobiecy obóz koncentracyjny. Warszawa 1961, s. 46.

38 Tamże, s. 49.

${ }^{39}$ Cyt. za: T. Wontor-Cichy: Więzieni za wiarę..., s. 148. Pierwotnie relacja byłej więźniarki publikowana była w „Strażnicy” (1981, nr 1), znajduje się ona też w Archiwum Państwowym Muzeum Auschwitz-Birkenau (Zespół Wspomnienia, t. 218, k. 219-225). 
Zadania, które kobiety Świadkowie Jehowy aprobowały, były wykonywane solidnie i ze szczególną dokładnością, dlatego Niemcy chętnie pozyskiwali takie pracownice. Z tego właśnie powodu we wrześniu 1942 roku komendant KL Auschwitz wydał formalne zezwolenie na zatrudnianie tych więźniarek $\mathrm{w}$ domach rodzin SS. Zostały tam dopuszczone do najbardziej zaufanych zadań, takich jak przygotowywanie posiłków czy opieka nad małymi dziećmi, otrzymały też dokumenty zezwalające na poruszanie się bez nadzoru po terenie przyobozowym ${ }^{40}$. (Nie bez znaczenia był na pewno fakt, że w większości były to kobiety posługujące się językiem niemieckim i Niemki). W ramach podjętych już obowiązków wykonywały wszystkie prace, również te najcięższe i najbardziej odrażające (jak czyszczenie latryn czy sprzątanie wymiocin po esesmańskich libacjach) ${ }^{41}$. Pod koniec wojny, kiedy Heinrich Himmler, korzystając z pośrednictwa Felixa Kerstena, organizował sobie kartę przetargową $\mathrm{w}$ postaci uwolnienia więźniarek i więźniów z obozów na terenie Rzeszy, ofiarował Kerstenowi posiadłość niedaleko Ravensbrück, a jako „prezent” przekazał też wybrane pracownice, którymi były kobiety Świadkowie Jehowy ${ }^{42}$. Doskonałe świadectwo wystawił niewolniczo pracującym „Bibelkom” komendant KL Auschwitz Rudolf Höss ${ }^{43}$.

I jeszcze ciekawostka z dziedziny antropologiczno-kulturowej: choć o niemieckich kobietach Świadkach Jehowy Wanda Kiedrzyńska pisze z uznaniem dla ich oporu, to o Polkach wyraża się $\mathrm{z}$ niechęcią i poczuciem wyższości: "Grupa badaczek Pisma świętego była wśród Polek bardzo nieliczna; należały do niej kobiety prymitywne, przeważnie pochodzenia chłopskiego" ${ }^{\text {"4 }}$. (Kiedrzyńska w ogóle prezentuje ten typ intelektualnego arystokratyzmu, który nie stroni od wskazywania na różne grupy kobiet jako na przykład „elementu najmniej wartościowego" czy „bardzo przypadkowego, w sumie trudnego do sklasyfikowania”45).

Znane autorki lagrowe (Zofia Kossak, Urszula Wińska, Maria Rutkowska-Kurcyuszowa) niemal nie odnotowują obecności kobiet Świadków Jehowy, a wziąwszy pod uwagę nacechowanie religijne ich relacji, można uznać ten deficyt za znaczący.

W innych tekstach pojawiają się ślady dobrej, tkliwej pamięci: „Kiedy Julia Skodowa miała spędzić w tym bloku pierwszą noc, blokowa - nazywała się Mitzi - przyszła do ich izby, życząc im w swoim wiedeńskim dialekcie: »Dobranoc, dzieci!«. "To tak, jakby mnie ktoś pogłaskał«, tak zadziałały te przyjazne

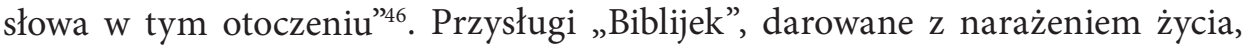

\footnotetext{
40 Por. tamże, s. 23-32.

${ }^{41}$ Zob. S. Helm: Kobiety z Ravensbrück..., s. 511.

42 Por. tamże, s. 480-481.

43 Por. Autobiografia Rudolfa Hössa..., s. 87-89.

44 W. KiedrZyńsKa: Ravensbrück..., s. 84.

45 Tamże, s. 86-87.

46 H. Langbein: Ludzie w Auschwitz..., s. 355.
} 
wspomina Irena Ciosińska pełniąca w Oranienburgu funkcję lekarki: „Znowu chodziłam brudna i bosa. [...] Zorganizowały szykowną sukienkę z czarnej wełenki i eleganckie półbuciki z jaszczurczej skórki (firma belgijska). Jak one przeszwarcowały te rzeczy z obozu do obozu pozostanie tajemnicą" ${ }^{\prime \prime 7}$.

3.

„Obóz dostarczył rzadkiej okazji do bezpośredniego zetknięcia się, nawet ścisłego współżycia, tak krańcowo różnych pod każdym względem kobiet; mogłoby stać się to przedmiotem specjalnych studiów socjologicznych"48 - pisała w monografii Ravensbrück była więźniarka. Stopniowo uobecnia się niewyrażony wprost postulat, z tym zastrzeżeniem, że przedmiotem badania zawładnęły $\mathrm{i}$ inne dziedziny humanistyki. Stojące na przecięciu dyscyplin pytanie o lagrową mikrospołeczność kobiet Świadków Jehowy powracać musi do sprawy ich fenomenu (jednak!), ponieważ zbyt łatwo byłoby tu stwierdzić jedynie religijny fanatyzm. Odpowiadając, nie można $\mathrm{w}$ zasadzie spostrzec niczego, co nie miałoby zastosowania do innych grup więźniów - kobiety Świadkowie Jehowy stawiały opór, wyrażały życzliwość, były pomocne, bohaterskie, cierpiały, ginęły. Wszak nie sama religijna odmienność przesądzała o tak często podkreślanym indywidualizmie tej grupy. Co więc? Indagacja ta staje się jeszcze bardziej paląca wobec faktu, że w zasadzie w każdym momencie Świadkowie Jehowy mogli „wypisać się" z obozu, parafując stosowne oświadczenie o wyrzeczeniu się wiary i zaprzestaniu religijnych praktyk ${ }^{49}$. Tymczasem nie tylko dalej umacniano się nawzajem w oporze, ale jeszcze wierność przekonaniom podnoszono do rangi świadomie podejmowanego męczeństwa.

Jedna z takich właśnie Badaczek Pisma Świętego, Polka z Poznańskiego, mówiła mi, że gdyby tylko złożyła podpis, że wyrzeka się swoich przekonań, to zaraz byłaby zwolniona $\mathrm{z}$ obozu. Ale nie słyszałam, aby którakolwiek $\mathrm{z}$ tych dzielnych kobiet załamała się w obozie... ${ }^{50}$.

Odpowiedzi na pytania o dyskutowany fenomen, o recepcję opisanych zachowań powinien chyba udzielić historyk/historyczka emocji. Rozwiązanie mogłoby być tym bardziej interesujące, iż wiemy, że Niemcy ostatecznie częściowo dostosowywali się do oporu wyrażanego przez Świadków Jehowy (nie kierowano

\footnotetext{
${ }^{47}$ I. Ciosińska: Po prostu miałam szczęście. Kraków 1989, s. 59-60.

48 W. KIEDRZYŃSKA: Ravensbrück..., s. 58-59.

${ }^{49}$ Por. T. Wontor-Сichy: Więzieni za wiarę..., s. 32-34.

50 J. Niedźwiadek: A jednak ocalałam. „Wieści” 1985, nr 16, s. 8.
} 
ich do pracy w przemyśle zbrojeniowym, zmieniono na mniej drastyczną formę deklaracji o wyrzeczeniu się wiary ${ }^{51}$ ).

Obiegową już frazą służącą do opisu lagrowego uniwersum jest stwierdzenie, że wolnościowe normy i wartości traciły tam zastosowanie, mówi się wręcz o „świecie odwróconym”, „antyświecie”, „innej planecie”, na względzie mając właśnie pogwałcone i zdekonstruowane imponderabilia. Odnoszę wrażenie, że zasada ta nie stosuje się do obozowych postaw kobiet Świadków Jehowy, poręczniejsza dla ich rozumienia może się zaś okazać refleksja z dziedziny antropologii kulturowej. Mam tu na myśli koncepcję wspólnot emocjonalnych opracowaną przez Barbarę H. Rosenwein, co prawda w odniesieniu do wczesnego średniowiecza, niemniej adaptowalną w ogólnym wymiarze do każdego „organizmu” społecznego.

Wspólnota emocjonalna to grupa, w której ludzie mają wspólne interesy, wartości i cele. Jest to więc często wspólnota społeczna. [...] Wspólnoty emocjonalne są więc poniekąd tym, co Foucault określał mianem wspólnego „dyskursu": wspólnym słownictwem i sposobami myślenia, które pełnią funkcję kontrolną, dyscyplinującą. Mają też wiele wspólnego z pojęciem "habitusu” wypracowanym przez Bourdieu: uwewnętrznionych norm determinujących to, jak działamy i myślimy, które zmieniają się w zależności od grupy ${ }^{52}$.

Nie przypadkiem Rosenwein mówi też o reżimie emocjonalnym, który w pewnym sensie bliski jest spopularyzowanemu znaczeniu słowa „fanatyzm”. Według badaczki wspólnota emocjonalna za wszelką cenę stara się zachować swój system uczuć i normy etyczne. Mają być one niezależne od okoliczności i utrzymane nawet w stanie wyjątkowym. Choć zmieniał się tryb egzystencji Świadków Jehowy, a zwykłe otoczenie zastąpione zostało obozem koncentracyjnym, to jednak zachowania i postawy pozostały nienaruszone. Nawet w rozproszeniu i szczególnych okolicznościach wyznawcy Jehowy utrzymywali więzi oraz naczelne imperatywy właściwe wyjściowemu systemowi. I to właśnie owa niewzruszoność, niezmienność uwspólnionych emocji wywołuje po dziś dzień konsternację, przechodzącą w wielu wypadkach w afektywne uznanie.

\section{Bibliografia}

Autobiografia Rudolfa Hössa komendanta obozu oświęcimskiego. Przeł. W. Grzymski. Warszawa 1989.

Ciosıńska I.: Po prostu miałam szczęście. Kraków 1989.

${ }^{51}$ Zob. T. Wontor-Cichy: Więzieni za wiarę..., s. 113-115.

${ }^{52}$ B.H. Rosenwein: Wspólnoty emocjonalne we wczesnym średniowieczu. Red. nauk. G. URban-Godziek. Przeł. L. Grzybowska, J. Szafrański, G. Urban-Godziek. Warszawa 2016, s. 49. 
Garbe D.: Between Resistance and Martyrdom: Jehovah's Witnesses in the Third Reich. Transl. D.G. Grimm. Madison, Wis. 1993.

GARBE D.: Zwischen Widerstand und Martyrium. Die Zeugen Jehovas im „Dritten Reich”. München 1999.

HAAS J.: Erinnerungsliteratur von Jehovas Zeugen als NS-Opfern. Frankfurt am Main 2013.

Helm S.: Kobiety $z$ Ravensbrück. Życie i śmierć w hitlerowskim obozie koncentracyjnym dla kobiet. Przeł. K. BAżyńsкA-СНојNACкA, P. СнојNACкі. Warszawa 2017.

KIEDRZYŃsKa W.: Ravensbrück. Kobiecy obóz koncentracyjny. Warszawa 1961.

Langbein H.: Ludzie w Auschwitz. Przeł. V. Grotowicz. Oświęcim 2017.

Liebster S.A.: W paszczy lwa. Mała dziewczynka stawia czoło reżimowi hitlerowskiemu. Przeł. A. Boczek. Wrocław 2007.

Lundholm A.: Wrota piekieł. Ravensbrück. Przeł. E. Czerwiakowska. Warszawa 2013.

Najodważniejsi byli zawsze Świadkowie Jehowy: prześladowania i sprzeciw Świadków Jehowy w okresie reżimu hitlerowskiego. Oprac. H. Hesse. Przeł. A. Boczek, J. BoCZEK. Wrocław 2006.

Niedźwiadek J.: A jednak ocalałam. „Wieści” 1985, nr 16, s. 8.

PAWEŁCZyńska A.: Wartości a przemoc. Zarys socjologicznej problematyki Oświęcimia. Warszawa 1995.

Rosenwein B.H.: Wspólnoty emocjonalne we wczesnym średniowieczu. Red. nauk. G. Urban-Godziek. Przeł. L. Grzybowska, J. Szafrański, G. Urban-Godziek. Warszawa 2016.

Strebel B.: KL Ravensbrück. Historia kompleksu obozów. Przeł. A. MilewsKa, M. Kurkowska. Słowo wstępne do wyd. pol. A. Gawlikowska-Świerczyńska, J. Muszkowska-Penson. Słowo wstępne G. Tillion. Gdańsk 2018.

Wachsmann N.: Historia nazistowskich obozów koncentracyjnych. Przeł. M. Antosiewicz. Warszawa 2016.

WŁoch W.: Stosunek Świadków Jehowy do wojen pierwszej połowy XX wieku. Doktryna i praktyka. „Zeszyty Naukowe Uniwersytetu Jagiellońskiego. Studia Religiologica” 2003, Vol. 36: Religie a wojna i terroryzm, s. 133-142.

Wontor-Cichy T.: Für den Glauben in Haft: Zeugen Jehovas im KL Auschwitz. Aus dem poln. Übers. A. BoczeK, J. HaAs. Oświęcim 2006.

Wontor-Cichy T.: Więzieni za wiarę. Świadkowie Jehowy w KL Auschwitz. Oświęcim 2003.

Barbara Czarnecka - pracownik Uniwersytetu w Białymstoku; studiowała (biologię i filologię polską), doktoryzowała się oraz habilitowała na Uniwersytecie Mikołaja Kopernika w Toruniu. Badaczka literatury emigracyjnej, redaktorka m.in. publicystyki i esejów oraz niepublikowanych wcześniej poematów Jerzego Pietrkiewicza, autorka książek Ruchomy na szali wagi. Lechon homotekstualny (2013) oraz Kobiety w lagrze. Zapis doświadczenia (2018). 